\title{
Fentanyl enhances the excitability of rapidly adapting receptors to cause cough via the enhancement of histamine release in the airways
}

\author{
Junzo Kamei ${ }^{*}$ Yuki Nakanishi, Megumi Asato and Hiroko Ikeda
}

\begin{abstract}
Background: Although the mechanism of fentanyl-induced cough is unclear, several lines of evidence suggest that allergic mediators, such as histamine, may play a role in the production of fentanyl-induced coughs. The aim of this study was to explore the effects of fentanyl on cough sensitivity to inhaled citric acid and on histamine release in BALF in mice.

Methods: The cough reflex was induced by the inhalation of citric acid. Male ICR mice were exposed to a nebulized solution of citric acid at a concentration of $0.1 \mathrm{M}$ under conscious and identical conditions using a body plethysmograph. The number of coughs produced per 3-min period of exposure to citric acid was counted. Histamine content in BALF was analyzed by HPLC post-column derivatization and fluorescence detection.

Results: Intravenous administration of fentanyl increased the number of citric acid-induced coughs. The fentanyl-induced enhancement of the number of citric acid-induced coughs was abolished in mice that had been pretreated with moguisteine, a rapidly adapting receptor (RAR) antagonist or fexofenadine, a histamine $\mathrm{H} 1$ receptor antagonist. Fentanyl significantly increased the concentration of histamine in BALF.
\end{abstract}

Conclusion: The results of this study suggest that fentanyl enhances the excitability of RARs to cause cough, and enhancement of histamine release in the airways may some how be related to this change.

\section{Background}

Fentanyl, a synthetic opioid, is a popular choice amongst anesthesiologists because of its quick onset, short duration of action, ease of titrability, intense analgesia, cardiovascular stability and low histamine release [1,2]. Although opioid agonists are known to possess antitussive activity, it is well known that i.v. administration of fentanyl paradoxically induces cough [3-7]. Fentanylinduced cough may be explosive at times, and may require immediate therapeutic intervention when it undesirably increases intracranial, intraocular or intraabdominal pressure [5-7]. Although the mechanism of fentanyl-induced cough is unclear, Agarwal et al. reported that pretreatment with salbutamol, beclomethasone or sodium chromoglycate reduced fentanyl-induced coughs [6]. These results strongly suggest that bronchoconstriction

\footnotetext{
* Correspondence: kamei@hoshi.ac.jp

Department of Pathophysiology and Therapeutics, School of Pharmacy and Pharmaceutical Sciences, Hoshi University, 4-41, Ebara 2-chome, Shinagawa,
} Tokyo 142-8501, Japan and/or allergic mediators, such as histamine and leukotrienes, may play a role in the production of fentanylinduced coughs.

We previously reported that although the inhalation of $0.1 \mathrm{M}$ citric acid by itself produced only a few coughs in guinea pigs, pre-exposure to histamine concentrationdependently increased the number of citric acid-induced coughs [8]. This histamine-induced increase in the number of citric acid-induced coughs was dose-dependently and significantly reduced when animals were pretreated with fexofenadine, a histamine $\mathrm{H} 1$ receptor antagonist. Based on these results, we suggested that histamine enhances the excitability of rapidly adapting receptors in response to tussive stimuli. It is well known that the activation of mast cells and the systemic release of histamine is a common side effect of opioids. While opioids exert antinociceptive effects, less frequent, but perhaps more profound, effects are the bronchoconstriction, edema and hemodynamic instability seen in some patients following intravenous bolus doses of opioids, 
such as morphine [9-13]. These effects have been attributed to histamine release from mast cells by opioids [9-13]. Although fentanyl has been reported to not cause the release of histamine in plasma [14], no previous study has examined the effects of fentanyl on histamine in bronchoalveolar lavage fluid (BALF).

Therefore, we hypothesized that i.v. fentanyl produces a cough reflex by increasing histamine release in BALF and enhancing cough sensitivity to tussive stimuli. Accordingly, the aim of this study was to explore the effects of fentanyl on cough sensitivity to inhaled citric acid and on histamine release in BALF in mice. The effect of fexofenadine, a histamine $\mathrm{H} 1$ receptor antagonist, on the effect of fentanyl on cough sensitivity to inhaled citric acid was also examined.

\section{Methods}

\section{Animals}

Male ICR mice (Tokyo Animal Laboratory Inc., Tokyo, Japan) weighing about $30 \mathrm{~g}$ were used. The animals had free access to food and water in an animal room that was maintained at $24 \pm 1^{\circ} \mathrm{C}$ with a 12-h light-dark cycle. These studies were carried out in accordance with the Declaration of Helsinki and/or with the guide for the care and use of laboratory animals as adopted by the committee on the care and use of laboratory animals of Hoshi University, which is accredited by the Ministry of Education, Culture, Sports, Science and Technology, Japan.

\section{Capsaicin- and citric acid-induced cough reflex}

The cough reflex was induced as previously described $[8,15]$. Briefly, animals were exposed to a nebulized solution of capsaicin at a concentration of $45 \mu \mathrm{M}$ or citric acid at a concentration of $0.1 \mathrm{M}$ under conscious and identical conditions using a body plethysmograph. The transducer was connected to a respiratory amplifier and polygraph to record a respiratory pattern. The transducer was also connected to respiratory analyzer and to a personal computer, which was used for on-line breathby-breath measurement. Capsaicin was dissolved to a concentration of $30 \mathrm{mg} / \mathrm{ml}$ in a $10 \%$ ethanol and $10 \%$ Tween 80 saline solution. The stock solution of capsaicin was diluted with saline to a concentration of $15 \mu \mathrm{M}$. Citric acid was dissolved to a concentration of $0.1 \mathrm{M}$ in a saline solution. The number of coughs produced per 3-min period of exposure to capsaicin or citric acid was counted.

\section{Effect of fentanyl on citric acid-induced coughs}

The mice were exposed for 3 min to citric acid $(0.1 \mathrm{M})$ $30 \mathrm{~min}$ before the i.v. injection of fentanyl $(5 \mu \mathrm{g} / \mathrm{kg})$ to determine the frequency of control coughs. The mice were also exposed for $3 \mathrm{~min}$ to citric acid $30 \mathrm{~min}$ after the i.v. injection of fentanyl. The number of coughs produced per 3-min period of exposure to citric acid 30 min after the i.v. injection of fentanyl was counted.

\section{Capsaicin pretreatment}

Capsaicin pretreatment was performed to evaluate the possible roles of vagal $\mathrm{C}$-fiber endings and their axonal reflexes in eliciting coughs. A total dose of $100 \mathrm{mg} / \mathrm{kg}$ capsaicin was divided into four portions $(20,20,30$, and $30 \mathrm{mg} / \mathrm{kg}$ ) and injected subcutaneously over 4 days under anaesthesia with ketamine $(50 \mathrm{mg} / \mathrm{kg}$, i.m.). Terbutaline $(0.1 \mathrm{mg} / \mathrm{kg}$, s.c.) and aminophylline $(25 \mathrm{mg} / \mathrm{kg}$, i.p.) were given to counteract the respiratory impairment associated with capsaicin injection. These animals were used for experiments 2 days after the last capsaicin pretreatment.

\section{Bronchoalveolar lavage fluid (BALF) collection}

BALF was collected from the lungs of mice that had been deeply anaesthetized with sodium pentobarbital $30 \mathrm{mg} / \mathrm{kg}$ (i.p.). BALF was obtained by injecting $2 \mathrm{ml}$ of ice-cold physiological saline $(1 \mathrm{ml}$, twice) via a tracheal cannula $30 \mathrm{~min}$ after i.v. injection of fentanyl $(5 \mu \mathrm{g} / \mathrm{kg})$. The collected BALF (approximately $1 \mathrm{ml}$ ) was centrifuged at $1600 \times \mathrm{g}$ for $10 \mathrm{~min}$. The supernatant fraction of the collected BALF was stored at $-80^{\circ} \mathrm{C}$ until assayed.

\section{Histamine assay}

Histamine was analyzed by HPLC post-column derivatization and fluorescence detection. The HPLC system consisted of an EP-300 pump (Eicom, Kyoto, Japan), an EHA-500 post-column reagent pump system (Eicom), an ATC-300 column oven (Eicom), a 231XL auto sampler (Gilson, Middleton, USA) and an L-7480 fluorescence detector (Hitachi, Tokyo, Japan). The mobile phase consisted of $0.16 \mathrm{~mol} / \mathrm{l} \mathrm{KH}_{2} \mathrm{PO}_{4}$ - methanol (97:3, v/v) containing $100 \mathrm{mg} / \mathrm{l}$ sodium 1 -octanesulfonate (flow rate, $0.3 \mathrm{ml} / \mathrm{min}$ ). Histamine was separated from other endogenous compounds on a reversed-phase column (Eicompak SC-5ODS; $3.0 \mathrm{~mm}$, i.d. $\times 150 \mathrm{~mm}, 5 \mu \mathrm{m}$, Eicom) maintained at $42^{\circ} \mathrm{C}$. The column elute was mixed with a mixture of $0.05 \mathrm{w} / \mathrm{v} \%$ $o$-phtalaldehyde (OPA) (flow rate, $0.06 \mathrm{ml} / \mathrm{min}$ ) and $2.5 \mathrm{~mol} / \mathrm{l} \mathrm{NaOH}$ (flow rate $0.06 \mathrm{ml} / \mathrm{min}$ ). Histamine was derivatized with OPA to form a fluorescent derivative in a reaction coil $(0.25 \mathrm{~mm}$, i.d. $\times 3 \mathrm{~m}$, PEEK) maintained at $42^{\circ} \mathrm{C}$. The reaction mixture was further mixed with $2 \mathrm{~mol} / 1 \mathrm{H}_{3} \mathrm{PO}_{4}$ (flow rate, $0.13 \mathrm{~mL} / \mathrm{min}$ ) in a mixing coil $(0.25 \mathrm{~mm}$, i.d. $\times 2 \mathrm{~m}$, PEEK) to adjust the $\mathrm{pH}$ of the final mixture. The fluorescence intensity of the final mixture was monitored at an excitation wavelength of $340 \mathrm{~nm}$ and an emission wavelength of $450 \mathrm{~nm}$, and recorded by an EPC-300 data processor (Eicom).

\section{Drugs}

Fentanyl hydrochloride was purchased from Covidien Japan Co. (Tokyo, Japan). Citric acid and capsaicin were 
purchased from Wako Junyaku Industries Co. (Tokyo, Japan) and Alpus Pharmaceutical Industries Co. (Gifu, Japan), respectively. Fexofenadine hydrochloride was generously supplied by Sanofi-Aventis K.K. (Tokyo, Japan). Histamine hydrochloride was purchased from Sigma-Aldrich Corporation (St. Louis, USA). Methanol and sodium 1-octanesulfonate were purchased from Nacalai Tesque Inc. (Kyoto, Japan). Ortho-phtalaldehyde (OPA) was purchased from Wako Pure Chemical Industries, Ltd. (Osaka, Japan). Other chemicals were of the highest purity available and used as received. Distilled water purified with a Milli-Q reagent water system (Millipore, Billerica, USA) was used for all aqueous solutions. Fentanyl and fexofenadine were dissolved in saline and 5\% DMSO, respectively. Moguisteine was suspended in $5 \%$ carboxylmethyl cellulose (CMC). Capsaicin was dissolved to a concentration of $30 \mathrm{mg} / \mathrm{ml}$ in a $10 \%$ ethanol and 10\% Tween 80 saline solution and was diluted with saline. Moguisteine and fexofenadine was administered s.c. 15 and $30 \mathrm{~min}$ before fentanyl injection, respectively.

\section{Statistics}

Data are expressed as means \pm S.E.M. The Mann-Whitney $U$-test was used to assess the statistical significance of differences in the number of coughs. Students' $T$ test was used to assess the statistical significance of differences in histamine contents in BALF. A level of probability of 0.05 or less was considered significant.

\section{Results}

\section{Effects of fentanyl on the number of citric acid-induced coughs}

Exposure to citric acid $(0.1 \mathrm{M})$ for 3 min produced about 6 coughs in mice. As shown in Figure 1, while i.v. pretreatment with saline did not significantly affect the number of citric acid-induced coughs, pretreatment with fentanyl at a dose of $5 \mu \mathrm{g} / \mathrm{kg}$, i.v., significantly increased the number of citric acid-induced coughs in mice.

\section{Effects of fentanyl on the number of citric acid-induced coughs in C-fiber desensitized (capsaicinized) mice} Exposure to capsaicin $(45 \mu \mathrm{M})$ for 3 min produced $11.6 \pm$ 1.1 coughs $(n=10)$ in vehicle-treated naive mice (noncapsaicinized mice). On the other hand, the number of coughs was significantly $(\mathrm{P}<0.05)$ reduced $(5.6 \pm 0.7$ coughs, $\mathrm{n}=10$ ) when capsaicin-pretreated mice (capsaicinized mice) were exposed to capsaicin $(45 \mu \mathrm{M})$ for 3 min. As shown in Figure 2, i.v. pretreatment with fentanyl at a dose of $5 \mu \mathrm{g} / \mathrm{kg}$, significantly increased the number of citric acid-induced coughs in both capsaicinized and non-capsaicinized mice. Pretreatment with capsaicin did not significantly affect the fentanyl-
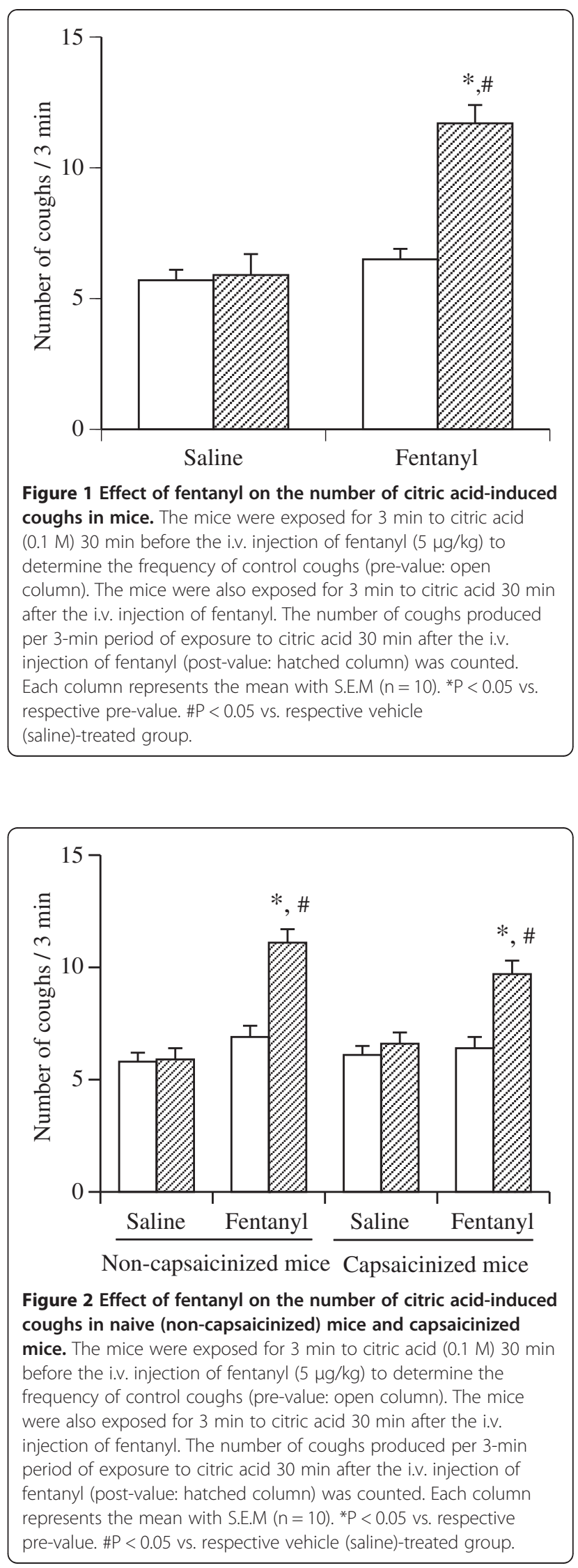

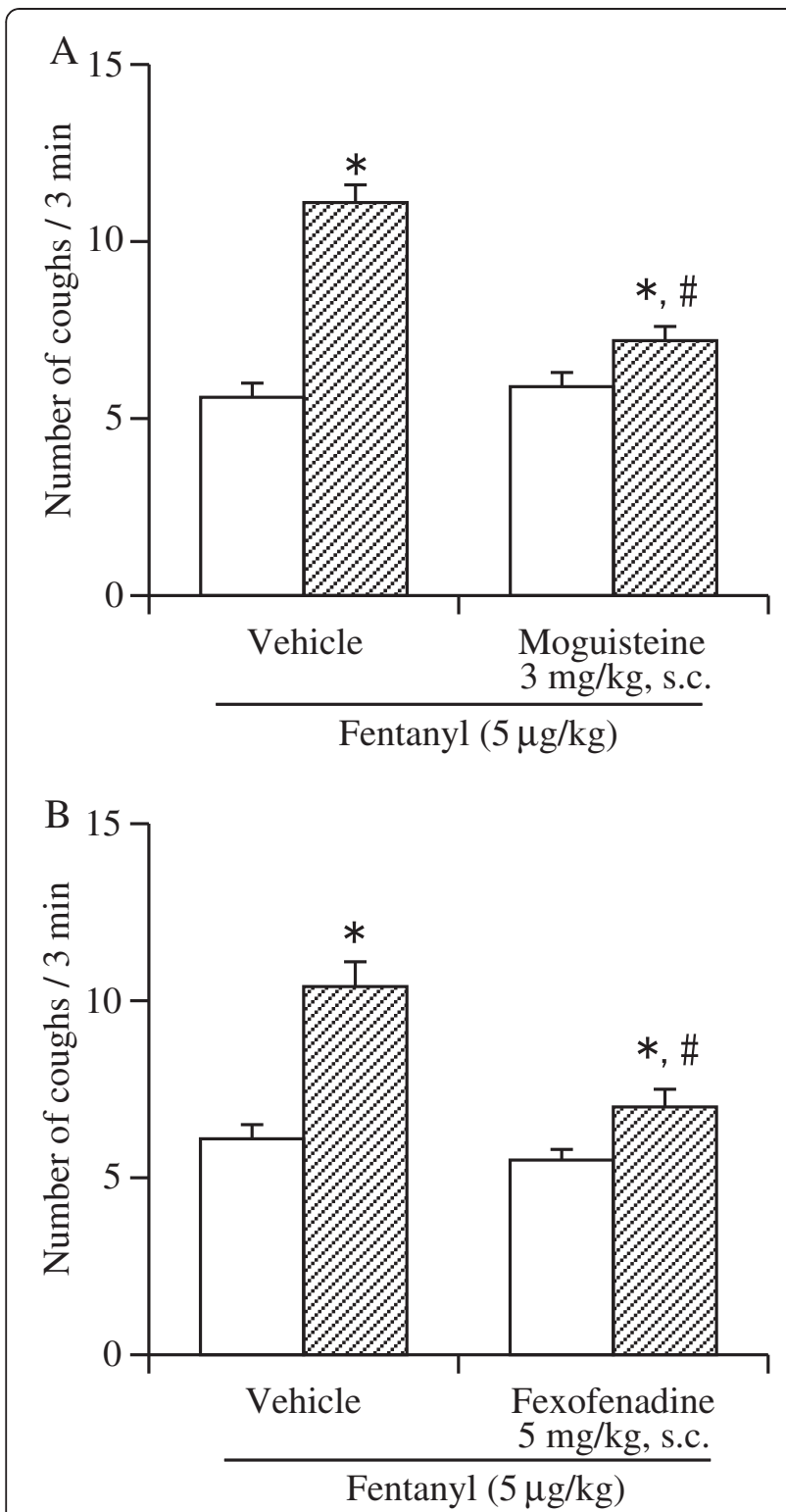

Figure 3 Effect of moguisteine (A) and fexofenadine (B) on the fentanyl-induced enhancement of the number of citric acidinduced coughs. The mice were exposed for $3 \mathrm{~min}$ to citric acid (0.1 M) 30 min before the i.v. injection of fentanyl $(5 \mu \mathrm{g} / \mathrm{kg})$ to determine the frequency of control coughs (pre-value: open column). The mice were also exposed for 3 min to citric acid $30 \mathrm{~min}$ after the i.v. injection of fentanyl. The number of coughs produced per 3-min period of exposure to citric acid 30 min after the i.v. injection of fentanyl (post-value: hatched column) was counted. Fexofenadine ( $5 \mathrm{mg} / \mathrm{kg}$ ) and it vehicle (5\% DMSO) were administered s.c. $30 \mathrm{~min}$ before the i.v. administration of fentanyl. Moguisteine and it vehicle ( $5 \%$ carboxylmethyl cellulose (CMC)) were administered s.c. 30 min before the i.v. administration of fentanyl. Each column represents the mean with S.E.M $(n=10) .{ }^{*} P<0.05$ vs. respective pre-value. $\# P<0.05$ vs. respective vehicle-treated group. induced enhancement of the number of citric acidinduced coughs.

Effects of moguisteine and fexofenadine on the fentanylinduced enhancement of the number of citric acidinduced coughs

As shown in Figure 3A, the fentanyl-induced enhancement of the number of citric acid-induced coughs was abolished in mice that had been pretreated with moguisteine $(3 \mathrm{mg} / \mathrm{kg}$, s.c.), a rapidly adapting receptor antagonist. Pretreatment with fexofenadine ( $5 \mathrm{mg} / \mathrm{kg}$, s.c.), a histamine $\mathrm{H} 1$ receptor antagonist, also abolished the fentanyl-induced enhancement of the number of citric acid-induced coughs (Figure 3B).

\section{Effect of fentanyl on the level of histamine in BALF}

The concentration of histamine in BALF was significantly increased in fentanyl $(5 \mu \mathrm{g} / \mathrm{kg}$, i.v.)-treated mice compared with that in vehicle-treated mice (Figure 4).

\section{Discussion}

The stimulation of capsaicin-sensitive bronchopulmonary unmyelinated $\mathrm{C}$-fibers is involved in elicitation of the cough reflex [16]. Tachykinins, like substance $\mathrm{P}$, which is contained in afferent $\mathrm{C}$-fiber endings within the airway epithelium and smooth muscle layer, are released by the activation of afferent $\mathrm{C}$-fibers. Bonham et al. reported that substance $\mathrm{P}$ stimulates rapidly adapting receptors in guinea pigs [17]. This stimulation of rapidly adapting receptors by substance $\mathrm{P}$ is a potential link between the two airway defense systems, both of which elicit bronchoconstriction, mucus secretion and cough.

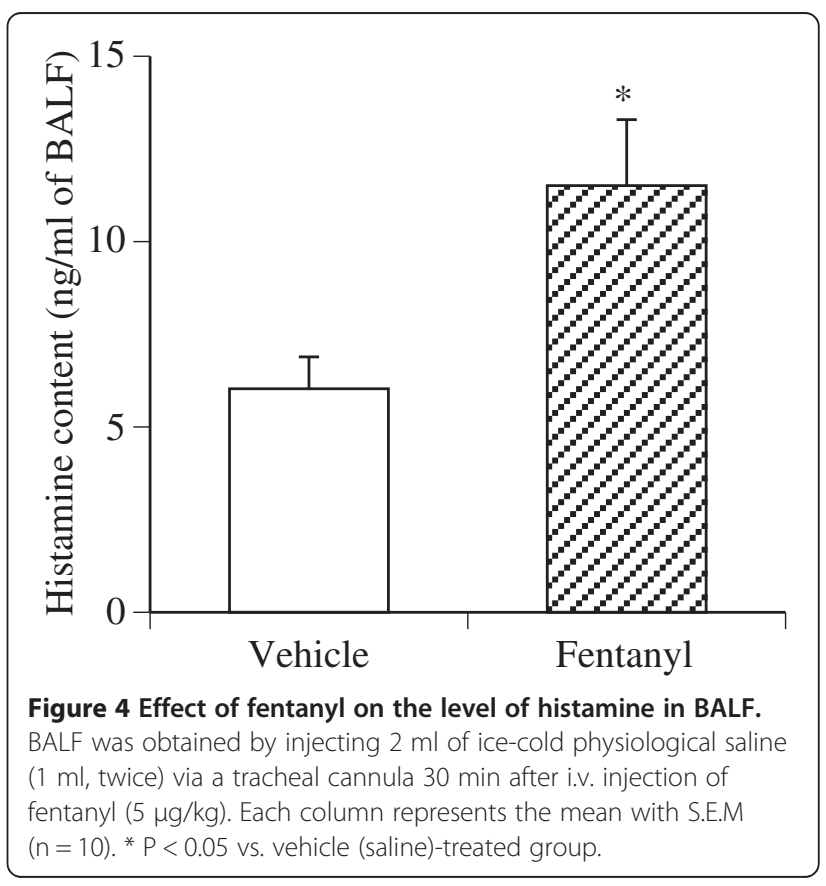


Such a link, by which C-fiber-receptor stimulation leads to the release of substance $\mathrm{P}$ and the subsequent stimulation of rapidly adapting receptors with myelinated $\mathrm{A} \delta$ fibers, has been previously proposed to explain the overlap of stimuli and reflex effects of both afferent systems [18]; i.e., the activation of C-fibers by capsaicin causes the release of substance $\mathrm{P}$ and the subsequent stimulation of rapidly adapting receptors, which may enhance cough reflexes. In the present study, we demonstrated that pretreatment with fentanyl significantly increased the number of citric acid-induced coughs in mice and that this effect was antagonized by pretreatment with moguisteine, a rapidly adapting receptor antagonist. Furthermore, the fentanyl-induced enhancement of the number of citric acid-induced coughs was also observed in capsaicin-pretreated C-fiber desensitized mice. Based on these results, it is likely that fentanyl activates mainly rapidly adapting receptors, but not $\mathrm{C}$-fibers, to enhance citric acid-induced coughs.

In the present study, we also demonstrated that fentanyl-induced enhancement of the number of citric acid-induced coughs was abolished by pretreatment with fexofenadine, a histamine $\mathrm{H} 1$ receptor antagonist. However, fexofenadine had no effect on the number of citric acid-induced coughs. Furthermore, in the present study, we also observed that fentanyl significantly increased the histamine levels in BALF. Previously, we demonstrated that pre-inhalation of histamine concentrationdependently and significantly increased the number of citric acid-induced coughs in guinea pigs, and this effect was antagonized by pretreatment with fexofenadine [15]. These results suggest that histamine may enhance cough receptor sensitivity through the activation of histamine $\mathrm{H}_{1}$ receptors in the airways. We also observed that the histamine-induced increase in the number of citric acid-induced coughs was concentration-dependently reduced when animals were pretreated with TNP-ATP, P2X-type ionotropic purinergic receptor antagonist [15]. Furthermore, we reported that the ATP-induced increase in the number of citric acid-induced coughs was concentration-dependently reduced when animals were pre-treated with TNP-ATP [19]. We also demonstrated that the ATP-induced increase in the number of citric acid-induced coughs was not abolished in C-fiberdesensitized guinea pigs [19]. On the other hand, inhaled ATP had no significant effect on the number of capsaicin-induced coughs in naive animals [19]. These results suggested that ATP activates $\mathrm{C}$-fiber-independent pathways, i.e., it directly activates rapidly adapting receptors, to enhance citric acid-induced coughs [19]. Tamesue et al. reported that histamine induced the release of ATP from segments of vas deferens, and this effect was blocked by pyridamine and triprolidine, histamine $\mathrm{H}_{1}$ receptor antagonists, but not by ranitidine, an
$\mathrm{H} 2$ receptor antagonist [20]. Furthermore, histamine also increased the release of ATP from superfused cultured smooth muscle cells [20]. The authors suggested that ATP might be released as an autacoid from smooth muscles in the presence of histamine [20]. Taken together, these results suggest that although histamine, by itself, does not directly modulate the sensitivity of the cough reflex, it is likely to enhance the excitability of rapidly adapting receptors and/or cough receptors in response to tussive stimuli via the modulation of ATP release in the airways. Based on our previous and present results, it is possible that fentanyl enhances the release of histamine in bronchoalveolar tissue and this histamine first enhances the excitability of rapidly adapting receptors through the activation of histamine $\mathrm{H} 1$ receptors and then causes a cough reflex.

Narcotic analgesics can induce the release of histamine both in vitro and in vivo in animals as well as in human. However, plasma histamine levels after i.v. injection of fentanyl are much less than those after the injection of morphine $[1,2,14]$. Furthermore, incubation of human skin mast cells with fentanyl did not induce the release of histamine [21]. However, in the present study, i.v. injection of fentanyl markedly increased the histamine levels in BALF. Although further studies are needed to determine the mechanisms that underlie these findings, it is possible that mast cell heterogeneity may play a role in the different effects of fentanyl on histamine release.

In conclusion, our present results suggest that fentanyl enhances the excitability of rapidly adapting receptors to cause cough. Furthermore, enhancement of histamine release in the airways might some how be related to fentanyl-induced enhancement of cough sensitivity. However, further studies are necessary before this possibility can be established with greater certainty.

\section{Competing interests}

All authors declare that they have no competing interests.

\section{Authors' contributions}

$\mathrm{YN}, \mathrm{HI}$ and MA conducted many of the experiments, analyzed the data and created the graphic summaries of the results. JK is general conductor of this study and wrote the manuscript. All authors read and approved the final manuscript.

Received: 4 August 2012 Accepted: 21 January 2013

Published: 1 February 2013

\section{References}

1. Grell FL, Koons RA, Denson JS: Fentanyl in anesthesia: a report of 500 cases. Anesth Analg 1970, 49:523-532.

2. Bovill JG, Sebel PS, Stanley TH: Opioid analgesics in anesthesia: with special reference to their use in cardiovascular anesthesia. Anesthesiology 1984, 61:731-755.

3. Böhrer $\mathrm{H}$, Fleischer $\mathrm{F}$, Werning P: Tussive effect of a fentanyl bolus administered through a central venous catheter. Anaesthesia 1990, 45:18-21.

4. Phua WT, Teh BT, Jong W, Lee TL, Tweed WA: Tussive effect of a fentanyl bolus. Can J Anesth 1991, 38:330-334

5. Tweed WA, Dakin D: Explosive coughing after fentanyl injection. Anesth Analg 2001, 92:1442-1443. 
6. Agarwal A, Azim A, Ambesh S, Bose N, Dhiraj S, Sahu D, Singh U: Salbutamol, beclomethasone or sodium chromoglycate suppress coughing induced by iv fentanyl. Can J Anesth 2003, 50:297-300.

7. Pandey CK, Raza M, Ranjan R, Lakra A, Agarwal A, Singh U, Singh RB, Singh PK: Intravenous lidocaine suppresses fentanyl-induced coughing: a double-blind, prospective, randomized placebo-controlled study. Anesth Analg 2004, 99:1696-1698.

8. Kamei J, Takahashi Y: Involvement of ionotropic purinergic receptors in the histamine-induced enhancement of the cough reflex sensitivity in guinea pigs. Eur J Pharmacol 2006, 547:160-164.

9. Rosow CE, Moss J, Philbin DM, Savarese JJ: Histamine release during morphine and fentanyl anesthesia. Anesthesiology 1982, 56:93-96.

10. Fahmy NR, Sunder N, Soter NA: Role of histamine in the hemodynamic and plasma catecholamine responses to morphine. Clin Pharmacol Ther 1983, 33:615-620

11. Philbin DM, Moss J, Akins CW, Rosow CE, Kono K, Schneider RC, VerLee TR, Savarese JJ: The use of $\mathrm{H} 1$ and $\mathrm{H} 2$ histamine antagonists with morphine anesthesia: a double-blind study. Anesthesiology 1981, 55:292-296.

12. Doenicke A, Moss J, Lorenz W, Hoernecke R: Intravenous morphine and nalbuphine increase histamine and catecholamine release without accompanying hemodynamic changes. Clin Pharmacol Ther 1995, 58:81-89.

13. Flacke JW, Flacke WE, Bloor BC, Van Etten AP, Kripke BJ: Histamine release by four narcotics: a double-blind study in humans. Anesth Analg 1987, 66:723-730

14. Warner MA, Hosking MP, Gray JR, Squillace DL, Yunginger JW, Orszulak TA: Narcotic-induced histamine release: a comparison of morphine, oxymorphone, and fentanyl infusions. J Cardiothorac Vasc Anesth 1991, 5:481-484.

15. Kamei J, Nakanishi Y, Ishikawa Y, Hayashi SS, Asato M, Ohsawa M: Possible involvement of tetrodotoxin-resistant sodium channels in cough reflex. Eur J Pharmacol 2011, 652:117-120.

16. Karlsson JA: The role of capsaicin-sensitive C-fibre afferent nerves in the cough reflex. Pulm Pharmacol 1996, 9:315-321.

17. Bonham AC, Kott KS, Ravi K, Kappagoda CT, Joad JP: Substance P contributes to rapidly adapting receptor responses to pulmonary venous congestion in rabbits. J Physiol 1996, 493:229-238.

18. Widdicombe JG: Neurophysiology of the cough reflex. Eur Respir J 1995, 8:1193-1202.

19. Kamei J, Takahashi Y, Yoshikawa Y, Saitoh A: Involvement of P2X receptor subtypes in ATP-induced enhancement of the cough reflex sensitivity. Eur J Pharmacol 2005, 528:158-161.

20. Tamesue S, Sato C, Katsuragi T: ATP release caused by bradykinin, substance $P$ and histamine from intact and cultured smooth muscles of guinea-pig vas deferens. Naunyn Schmiedebergs Arch Pharmacol 1998, 357:240-244.

21. Blunk JA, Schmelz M, Zeck S, Skov P, Likar R, Koppert W: Opioid-induced mast cell activation and vascular responses is not mediated by mu-opioid receptors: an in vivo microdialysis study in human skin. Anesth Analg 2004, 98:364-370.

doi:10.1186/1745-9974-9-3

Cite this article as: Kamei et al:: Fentanyl enhances the excitability of rapidly adapting receptors to cause cough via the enhancement of histamine release in the airways. Cough 2013 9:3.

\section{Submit your next manuscript to BioMed Central and take full advantage of:}

- Convenient online submission

- Thorough peer review

- No space constraints or color figure charges

- Immediate publication on acceptance

- Inclusion in PubMed, CAS, Scopus and Google Scholar

- Research which is freely available for redistribution

Submit your manuscript at www.biomedcentral.com/submit 